\title{
Employer brand and workforce performance in hotel companies
}

\author{
Jasmina Ognjanovici ${ }^{1^{*}}$ \\ ${ }^{1}$ University of Kragujevac, Faculty of Hotel Management and Tourism in Vrnjačka Banja, \\ Serbia
}

\begin{abstract}
Employer brand represents an intangible asset which is the result of successful implementation of employer branding strategy that promotes the company as exceptional employer, provides the candidates with realistic expectations and fulfills the promises made to all employees. The main aim of the research is to prove that hotel companies should be strongly encouraged to develop employer brand, since this is one of the best ways to increase workforce performance. In terms of business operations, employer brand is monitored by means of appropriate dimensions (training and development, employer reputation, work/life balance, corporate social responsibility, business culture). Testing of research hypotheses was performed using regression analysis and ANOVA test. Results indicate statistically significant impact of employer brand on workforce performance and statistically significant difference in the level of accomplished average workforce performance among different category hotels.
\end{abstract}

Keywords: employer brand, workforce performance, hotel

JEL classification: J24, J32, L25

\section{Brend poslodavca $i$ performanse radne snage $u$ hotelskim preduzećima}

Sažetak: Brend poslodavca predstavlja neopipljivu, nematerijalnu imovinu nastalu kao rezultat uspešne implementacije strategije brendiranja poslodavca koja promoviše kompaniju kao odličnog poslodavca, pruža realna očekivanja kandidatima sa tržišta rada i ispunjava data obećanja zaposlenima. Cilj istraživanja jeste da se dokaže da hotelska preduzeća moraju razvijati imovinu brenda poslodavca, jer je to jedan od načina da uvećaju performanse radne snage. Brend poslodavca u radu prati se putem odgovarajućih dimenzija (obuka i razvoj, reputacija poslodavca, balans između života i posla, korporativna društvena odgovornost, poslovna kultura). Testiranje istraživačkih hipoteza vrši se primenom regresione analize i uz pomoć ANOVA testa. Rezultati ukazuju na statistički značajan uticaj brenda poslodavca na performanse radne snage. Takođe, dokazana je statistički značajna razlika u nivou ostvarenih prosečnih performansi radne snage između hotela različitih kategorija.

Ključne reči: brend poslodavca, performanse radne snage, hotel JEL klasifikacija: J24, J32, L25

* jasmina.lukic@kg.ac.rs 


\section{Introduction}

Human resources are considered to be the most critical asset of a company (Aleksić Glišović et al., 2019; Rai, 2020; Tanwar \& Prasad, 2017) and the crucial factor of company's sustainable efficiency (Razak et al., 2012). During the 1990s, the companies started to grasp the relevance of human resources for achieving competitive advantage over their rivals (Sharma \& Prasad, 2018). Maurya and Agarwal (2018) saw talented human resources as crucial competitive driving force of organizational performance. Having in mind the importance of human resources for company's operation, there was a need for defining the concept which would satisfy the need of the company to attract and keep valuable employees. By developing the employer brand, the companies could position themselves on competitive labor market (Schlager et al., 2011) and achieve top business performance through improved work efficiency. The concept of employer brand is essential in knowledgeintensive contexts, hospitality industry services included (Schlager et al., 2011). As human resources are of vital importance for hospitality industry and its business activities, employer brand is to be developed as HRM tool which aims at: attracting talented individuals from labor market (1), increasing workforce performance, satisfaction and motivation of employees (2), and keeping valuable employees in hotels (3).

Research has proved that "human capital has crucial and positive associations with organizational productivity, performance and long-term competitive advantage” (Zhu et al., 2014, p. 934). Employer branding is a process which aims at efficient utilization of human capital and creation of satisfied employees. Such employees achieve top results, which is the final outcome of employer branding process. However, research effort that analyzes the correlation between employer brand and workforce performance, and the impact that the employer brand has on these performances is rather modest. Relevant studies have proved the impact of employer brand on employee engagement (Chawla, 2020; Davies et al., 2018), employee satisfaction (Ognjanović \& Slavković, 2019; Tanwar \& Prasad, 2016), employee loylity (Benraiss-Noailles \& Viot, 2020), but no study has focused on the impact of employer brand on workforce performance. This study aims at overcoming the stated research gap. Additionally, the scale which has been used for assessing employees is now used for assessing employer brand. Previously used scales (EmpAt) have been efficient for the employer brand analysis from the perspective of potentially employed, but are probably not the best solution for the analysis from the perspective of current employees (Tanwar \& Prasad, 2016).

The main aim of the research is to prove that hotel companies should be strongly encouraged to develop employer brand, since this is one of the best ways to increase workforce performance. In terms of business operations, employer brand is monitored by means of appropriate dimensions (training and development, employer reputation, work/life balance, corporate social responsibility, business culture). Workforce performances measure employees' work results expressed in quantitative units. As employer brand implies specific benefits that employers offer to employees, it is expected that employees shall aim at achieving better results if they are provided with such benefits. Therefore, it is necessary to do additional research and offer adequate answers to the following questions: which dimensions of employer brand are developed in hotels, can the development of employer brand have positive impact on employees' performance, and are there any differences in the level of average workforce performance between hotels of different categories? 


\section{Literature review}

\subsection{Employer brand concept}

Lack of human capital has resulted in the increased demand for management and expertise skills at the relevant labor market (Arasanmi \& Krishna, 2019). In order to overcome this problem, majority of companies have realized that developing an outstanding employer branding strategy is crucial for making companies competitive and attractive for valuable candidates at the labor market (Tanwar \& Prasad, 2016). The primary objective of employer branding is to differentiate a specific company from competition at the labor market (Tanwar \& Prasad, 2016). Sharma and Prasad (2018) state that employer branding implies applying branding efforts to human resource management, i.e. creating the image of a company as "good place of work" for potential and current employees. Consequently, the company establishes a distinctive image of attractive employer for both currently employed and potential new employees (Zhu et al., 2014). Employer brand represents an intangible asset which is the result of successful implementation of employer branding strategy that promotes the company as exceptional employer, provides the candidates with realistic expectations and fulfills the promises made to all employees.

Branding, which has traditionally been focused on products, is now applied by employers for human resources (Tanwar \& Prasad, 2016). Employer branding utilizes the principles of branding for the activities of human resource functions and the ways that an organization should be shown to current and potential employees (Rai, 2020). The concept of employer brand has derived from "corporate branding theory, largely as a result of the application of ideas on influencing customers to human resource management (HRM) and to its influence over potential and existing employees” (Davies et al., 2018, p. 64). Employer branding process is focused on two target groups: insiders (employees) and outsiders (potential employees) (Saini \& Jawahar, 2019). Tanwar and Prasad (2016) consider that employer branding can make expected results only if the employer is seen as attractive by current employees (insiders). Therefore, enhancement of employer brand can be done with the help of valuable and efficient employees. The primary goal of the company is to keep efficient employees and increase their productivity, which is often accomplished by developing specific dimensions of employer brand that potential employees prefer. Additionally, the objective of development of employer brand is to attract new and talented individuals who are present at the labor market (outsiders), thus strengthening human capital. The stated objectives can be successfully accomplished by building specific employer brand dimensions (benefits) that make employer different from the competition and that are promised to potential employees. Employer brand dimensions are boosted by the company's employees who are the initiators of employer branding process. Having in mind the importance of employees in employer branding process, the employer brand analysis has been from the perspective of current employees.

Practitioners and researchers state that development of efficient employer branding strategies can offer strategic advantage to companies through the improvement of engaged employees who are loyal and committed to the company, and whose engagement aims at accomplishing superior goals of the company (Chawla, 2020). Employer branding is recognized as key factor for achieving business success which encourages cognitive and organizational connection among employees, as well as positive engagement of other company members (Maurya \& Agarwal, 2018). The entire process is dedicated to securing appropriate level of identification of employees with the company (Schlager et al., 2011), which encourages engaged employees. Arasanmi and Krishna (2019) consider that meeting expectations and aspirations of employees by developing adequate employer brand dimensions can have a 
positive impact on employee support, affection and assistance, which is also reflected on company's organizational performances. As the employees create employer brand, "the company should make sure that employees "live" the brand, in order to develop confidence and generate positive attitude by delivering brand promises through employer brand attributes” (Tanwar \& Prasad, 2016, p. 857). Therefore, employer brand enhancement should aim at providing appropriate employee engagement and commitment in order to accomplish the planned results and targets of business operations.

Employer brand dimensions represent benefits (functional, psychological and economic) that the employer provides to the employees. Employee dedication and engagement largely depend on preferences and level of development of employer brand dimensions. The pioneers of research in this area, Ambler and Barrow (1996), have defined the benefits that employees acquire working for the employer (psychological, functional and economic). The initial definition has been expanded by Berthon et al. (2005) who adds interest, social, development, application and economic value. Numerous authors have based their research on all of the above stated dimensions. This paper shall analyze the following dimensions of employer brand: training and development, employer reputation, life/work balance, corporate social responsibility and business culture (Tanwar \& Prasad, 2016).

Training and development represent "the extent to which an individual is attracted to an employer who provides recognition, generates a feeling of self-worth, and provides a careerenhancing experience and a springboard to future employment” (Zhu et al., 2014, p. 935). Research points to the correlation between employee training and development, and workforce productivity (Chhetri et al., 2018), as well as its correlation with organizational performance (Otoo et al., 2019; Rana \& Malik, 2017). Employer reputation is defined as the way the company is seen by the individuals seeking employment (Schlager et al., 2011). Moroko and Uncles (2008) regard reputation as one of the integral elements of employer branding process. Maurya and Agarwal (2018) consider that employer brand and organization reputation are the key to success of every business operation. Relationship between employer brand and reputation is thoroughly analyzed in research that concludes that individuals prefer to work in a company with positive reputation, even if it means working for lower salary (Benraiss-Noailles \& Viot, 2020). Work/life balance refers to keeping balance between employee's personal and professional life. The companies that have developed this dimension of employer brand are becoming more and more attractive on labor market (Sharma \& Prasad, 2018). Tanwar and Prasad (2016) emphasize that the companies will not be able to develop employer brand if they do not invest in work/life balance. Corporate social responsibility (CSR) measures the impact that companies have on society in general. In return, socially responsible companies are able to engage new employees and attract new buyers. CSR is increasingly present as a topic in research where the relationship between CSR and employee's behavior is especially emphasized (Grubor et al., 2020). Authors Sharma and Prasad (2018) emphasize that numerous studies have confirmed that CSR has a positive impact on both current and future employees. Business culture represents the set of values and beliefs that the company's employees create, implement and respect. Literature supports business culture as an important factor of employer branding (Arasanmi \& Krishna, 2019).

The stated dimensions reflect specific benefits which shall be the base for analyzing the employer brand in hotel companies. By developing employer brand dimensions, hotels have created a positive and satisfactory work environment and thus improved employees' professional results which are monitored by means of workforce performance. 


\subsection{Workforce performance}

Along with other relevant organizational variables, qualified workforce makes a significant contribution to business success and efficiency in highly competitive business environment (Musah et al., 2016). Employees' professional results and contribution to the implementation of business targets are monitored by means of specific performances. Workforce performance refers to the activities and tasks that employees carry out in an efficient and effective manner (Ahmad et al., 2015). In the search of the answer to the question- how to develop a system which will have the potential to improve employee productivity and workforce performance, McAfee and Champagne (1993) state that performance management could represent a good solution. Measuring and monitoring of workforce performance result in the enhancement of total efficiency and productivity of overall organization process (Ahmad et al., 2015). Bitmiş and Ergeneli (2013) and Khan et al. (2019) have discussed the importance of workforce performance for achieving satisfactory business performances of organizations.

Valuable workforce generates efficiency and high productivity within a company (Musah et al., 2016). Authors Schlager et al. (2011) have made a connection between employer branding and employee outcomes, bearing in mind that the company monitors the needs and desires of employees by means of employer brand dimensions. Employer branding is focused on understanding the attitudes and feelings of workforce, as this is crucial for achieving efficient performances and outstanding work results (Musah et al., 2016). Additionally, employer brand offers specific benefits and rewards which have a positive impact on employee performances (Itam et al., 2020). Employees' work results depend on their engagement, which Chawla (2020) connects with employer branding strategy. "Employee engagement can thus be defined as positive, fulfilling, work-related state of mind that is characterized by vigor, dedication, and absorption" (Chawla, 2020, p. 2). The initial assumption is that development of employer brand has a positive impact on employee behavior, engagement and commitment, which again affects workforce performance and consequently employees’ work results.

The research that has analyzed the correlation between employer brand and employee behavior concludes that companies with strongly organized and committed workforce can improve organizational performances, and increase company productivity and competitiveness (Arasanmi \& Krishna, 2019). Davies et al. (2018) have pointed out that "satisfaction partially mediates the influence of employer brand image on engagement of employee” (p. 64). Author Chawla (2020) emphasizes that employer branding has a positive correlation with employee engagement. Benraiss-Noailles and Viot (2020) underline the impact of employer brand on positive employee well-being, which in turn, influences loyalty of employees. Schlager et al. (2011) have proved the impact of two dimensions of employer brand- social value and reputation value, on current employee identification. Tanwar and Prasad (2016) have demonstrated the impact of all observed dimensions of employer brand on job satisfaction. Ognjanović and Slavković (2019) have verified the impact of employer brand on satisfaction of employees working in hotel companies.

The following hypotheses have been defined based on the research objective, observed employer brand dimensions and workforce performance:

$H_{1}$ : Employer brand has positive and statistically significant impact on workforce performances.

$\mathrm{H}_{2}$ : There is a statistically significant difference in the level of achieved average workforce performances for hotels with different categories. 


\section{Research instruments and statistical methods}

The sample consisted of 34 hotels which were operational in 2017 in the Republic of Serbia within the scope of sector I - accommodation and food service, activity code 5510 - Hotels and similar accommodation (Decree on Activity Classification of RS, 2010, p. 124). Information on the number of companies and their activity code - 5510 were taken from Business Registry Agency of the Republic of Serbia (2017). Data necessary for conducting the research on employer brand dimensions and workforce performances were collected by means of questionnaires, which were sent to 418 emails of various hotels. Hotels returned the total of 34 filled out questionnaires, which meant that response rate was $8 \%$. The research was carried out during 2017.

Hotel employees had to meet two criteria in order to be eligible for research participation. Firstly, the tested subjects had to be employed at III, IV or V category hotel. Secondly, they had to be hotel managers, as they were most competent employees who could assess workforce performance and the level of development of employer brand dimensions in hotels. The reason for excluding hotels of I and II category was the assumption that employer brand was not sufficiently developed. The questionnaire consisted of three parts: the first part implied questions which referred to employee and hotel features, the second part measured employer brand dimensions and the third part measured workforce performance. Research questionnaire contained the total of 22 statements measured based on five-level Likert scale which ranged from 1 - "strongly disagree" to 5 - "strongly agree”. Employer brand was analyzed through the following dimensions: training and development, employer reputation, work/life balance, corporate social responsibility and business culture (Tanwar \& Prasad, 2016). The part of the questionnaire which measured employer brand dimensions was created based on research of Tanwar and Prasad (2016) and Zhu et al. (2014), while the part which measured workforce performances was generated based on the research conducted by Baumann et al. (2016) and Musah et al. (2016).

The sample was analyzed in terms of hotel category, tested subjects' education level, years of experience in hospitality industry and subjects' position at the hotel. Majority of the analyzed hotels were hotels of III (50\%) and IV (47\%) category. Additionally, majority of managers had a college degree ( $44 \%$ of the total sample), had up to 5 years of experience in hospitality industry (50\%) and were employed as first-line managers, i.e. functional managers (53\% of the sample).

\section{Research results and discussion}

\subsection{Descriptive statistics}

The development of employer brand dimensions at analyzed hotels was monitored by mean value. The highest mean value was recorded for employer reputation dimension (Mean = 3.882), while the lowest value was recorded for training and development dimension (Mean $=2.971$ ) (Figure 1). The obtained results indicated that the tested subjects considered that employer reputation was closely related to employer brand, as well as that hotels permanently worked on promoting hotel reputation as exceptional employer on labor market. The mean value for dimension training and development clearly specified that hotels did not invest sufficient funds in employee training and development, which seemed as one of the crucial downsides, especially in terms of HRM practice. 
Figure 1: Development of employer brand dimension for analyzed hotels

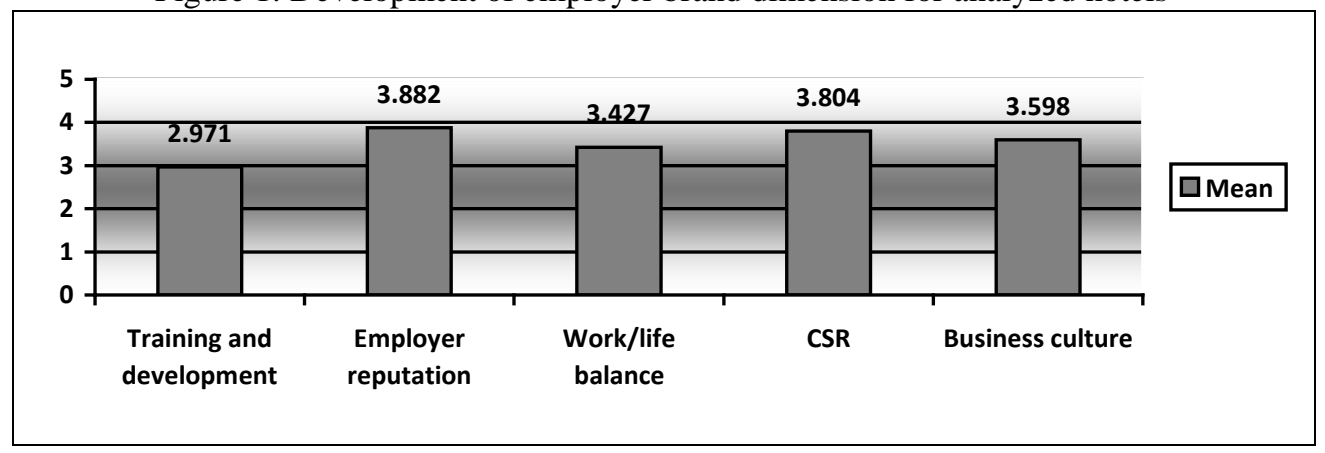

Source: Author's research

Mean value for variable workforce performances was 4.177. The highest value of standard deviation was recorded at corporate social responsibility variable $($ St. Dev. $=1.295)$. The obtained values of skewness were negative, which meant that the results were distributed in a way which was closer to higher values. Majority of obtained kurtosis results were negative, which meant that the distribution was much more flat than normal.

\subsection{Reliability analysis}

Reliability of the observed variables was measured based on the value of Cronbach's alpha coefficient. The value of the coefficient for the entire model was 0.877 , which meant that consistency and reliability of the variables was satisfactory or even higher than the recommended minimum value 0.7 (Nunnally, 1978). Moreover, value of Cronbach's alpha coefficient for individual variables ranged from 0.827 (business culture) to 0.886 (work/life balance) (Table 1).

Table 1: Results of reliability analysis

\begin{tabular}{|l|c|}
\hline Variable & Cronbach's alpha coefficient \\
\hline Training and development & 0.860 \\
\hline Employer reputation & 0.832 \\
\hline Work/life balance & 0.886 \\
\hline CSR & 0.843 \\
\hline Business culture & 0.827 \\
\hline Workforce performances & 0.879 \\
\hline
\end{tabular}

Source: Author's research

\subsection{Correlation analysis}

Correlation analysis results were used for monitoring the strength and direction of correlation between the variables. Correlation strength was defined based on the Pearson coefficient. Correlation coefficient between 0.10 and 0.29 indicated weak correlation between the variables, values from 0.30 to 0.49 indicated medium correlation, while values over 0.50 indicated strong correlation between the variables (Pallant, 2009). Positive/negative values of correlation coefficient pointed to the direction of the connection. If the values were positive, growth of one variable would result in the growth of another variable, and vice versa. On the other hand, if the values were negative, growth of one variable would result in the drop of another variable, and vice versa. 
Table 2: Correlation matrix

\begin{tabular}{|l|c|c|c|c|c|c|}
\hline & $\begin{array}{c}\text { Training and } \\
\text { development }\end{array}$ & $\begin{array}{c}\text { Employer } \\
\text { reputation }\end{array}$ & $\begin{array}{c}\text { Business } \\
\text { culture }\end{array}$ & $\begin{array}{c}\text { Work/life } \\
\text { balance }\end{array}$ & CSR & $\begin{array}{c}\text { Workforce } \\
\text { performances }\end{array}$ \\
\hline $\begin{array}{l}\text { Training and } \\
\text { development }\end{array}$ & 1 & & & & & \\
\hline $\begin{array}{l}\text { Employer } \\
\text { reputation }\end{array}$ & $0.656^{* *}$ & 1 & & & & \\
\hline Business culture & $0.704^{* *}$ & $0.791^{* *}$ & 1 & & & \\
\hline $\begin{array}{l}\text { Work/life } \\
\text { balance }\end{array}$ & 0.318 & $0.479^{* *}$ & $0.424^{* *}$ & 1 & & \\
\hline CSR & $0.555^{* *}$ & $0.698^{* *}$ & $0.760^{* *}$ & $0.574^{* *}$ & 1 & \\
\hline $\begin{array}{l}\text { Workforce } \\
\text { performances }\end{array}$ & $0.423^{*}$ & $0.625^{* *}$ & $0.558^{* *}$ & 0.253 & $0.342 *$ & 1 \\
\hline * Correlation is statistically significant on the level of 0.05 \\
** Correlation is statistically significant on the level of 0.000
\end{tabular}

Source: Author's research

After observing the correlation between employer brand dimensions, it could be concluded that all dimensions, except work/life balance, had strong and statistically significant correlation, especially in terms of business culture and reputation $(\rho=0.791 ; p=0.000)$. The weakest correlation, which was not even statistically significant, was recorded between work/life balance and training and development $(\rho=0.318 ; p=0.066)$. The analysis of correlation between workforce performance and employer brand dimensions pointed out that the correlation could be defined as medium and strong. The strongest correlation was recorded between reputation and workforce performances $(\rho=0.625 ; p=0.000)$, while statistically insignificant correlation was recorded between work/life balance and workforce performances $(\rho=0.253 ; p=0.148)$ (Table 2).

\subsection{Regression analysis}

Testing the impact of employer brand on workforce performance was carried out by applying multiple regression analysis. Such procedure implied the analysis of fulfillment of specific assumptions relevant for the application of this model. The assumptions referred to multicollinearity and autocorrelation analysis. Multicollinearity, i.e. high level of correlation between the variables was measured based on VIF coefficient, which should not be higher than 5. Autocorrelation was measured based on Durbin-Watson statistics, which should not be higher than 4 . In terms of the analyzed research model, VIF coefficient was lower than 5 for all dimensions of employer brand (Table 3), while Durbin-Watson statistics for the observed model was 1.911, which confirmed that the assumptions for conducting regression analysis were fulfilled. 
Table 3: Results of regression analysis

\begin{tabular}{|l|c|c|c|c|c|}
\hline \multirow{2}{*}{\multicolumn{1}{c|}{$\begin{array}{c}\text { Employer brand } \\
\text { dimensions }\end{array}$}} & \multicolumn{5}{c|}{ Standard multiple regression } \\
\cline { 2 - 6 } & $\boldsymbol{\beta}$ & $\mathbf{t}$ & Sig. & Tolerance & VIF \\
\hline Training and development & -0.041 & -0.201 & 0.842 & 0.478 & 2.093 \\
\hline Employer reputation & 0.582 & 2.348 & $\mathbf{0 . 0 2 6} *$ & 0.323 & 3.096 \\
\hline Business culture & 0.375 & 1.328 & 0.195 & 0.249 & 4.022 \\
\hline Work/life balance & 0.025 & 0.141 & 0.889 & 0.648 & 1.542 \\
\hline CSR & -0.341 & -1.406 & 0.171 & 0.337 & 2.968 \\
\hline
\end{tabular}

Dependent variable: Workforce performance

Significance: $* \mathrm{p} \leq 0.05$

$\mathrm{R}^{2}=0.445 ; \mathrm{F}=4.492 ; \mathrm{p}=0.004$

Source: Author's research

Based on the obtained results of regression analysis, one could conclude that hypothesis $\mathrm{H}_{1}$ was accepted $(p=0.004)$, i.e. statistically significant impact of employer brand dimension on workforce performance of hotel companies was proved. Coefficient of determination $\mathrm{R}^{2}$ was 0.445 , which meant that $45 \%$ of workforce performance variability was explained by means of regression model, while the remaining part was under the influence of other factors. Having in mind that the sample was rather modest $(n=34)$, the value of Adjusted $R$ Square was 0.346. Value of F-statistic was 4.492. Based on the values of $\beta, t$ and Sig. given in Table 3, it could be concluded that employer reputation dimension had statistically significant impact on workforce performance. The highest value of $\beta$ coefficient was recorded for employer reputation dimension $(\beta=0.582)$. This practically meant that, after deducting the variable which was explained by other model dimensions, employer reputation made the most significant contribution to the clarification of workforce performance. Moreover, the results indicated that employer reputation $(\beta=0.582 ; \mathrm{t}=2.348 ; \mathrm{p}=0.026) \mathrm{had}$ positive and statistically significant impact on workforce performance.

\subsection{ANOVA test}

Testing of hypothesis $\mathrm{H}_{2}$ was carried out by means of one-way analysis of variance of various groups (ANOVA), which was based on comparison of average results of more than two groups (Pallant, 2009, p. 249). The application of this analysis was rather convenient for examining the difference between average values of workforce performance in hotels of different categories. The analyzed hotels were divided into three groups: hotels of III, IV and $\mathrm{V}$ category. The assumption for implementation of ANOVA analysis was tested based on Levene's test of homogeneity of variance which tested equality of variance in the results of each of the three analyzed groups (Pallant, 2009, p. 253). Significance value for Levene's test was $p=0.144$, which meant that variance homogeneity assumption was not affected and the conditions for conducting ANOVA analysis are fulfilled.

Table 4: Results of ANOVA test

\begin{tabular}{|l|c|c|c|c|c|}
\hline & Sum of Squares & Df & Mean Square & F & Sig. \\
\hline Between Groups & 6.304 & 2 & 3.152 & 4.697 & 0.017 \\
Within Groups & 20.804 & 31 & 0.671 & & \\
Total & 27.108 & 33 & & & \\
\hline
\end{tabular}

Source: Author's research 
The obtained results confirmed statistically significant difference at the level of $p \leq 0.05$ in terms of the results of three categories of hotels $\mathrm{F}_{(2,31)}=4.697$; $\mathrm{p}=0.017$ (Table 4). Hypothesis $\mathrm{H}_{2}$ was accepted, which practically meant that there was a statistically significant difference in the level of accomplished average workforce performances among the hotels of different categories. Based on the obtained value of Eta-squared (0.233), significant difference between mean values of workforce performance could be confirmed. Additional comparison conducted based on Tukey's HSD test indicated that mean value of workforce performance of III category hotels (Mean=4.489, St. Dev. $=0.547$ ) was significantly different from the mean value of workforce performance of IV category hotels (Mean=3.667, St. Dev.=1.117).

Hotel employees assess the employer reputation dimension as the most developed. By developing a reputation in the external and internal environment, hotels are becoming more attractive to both labor market candidates and current employees. The essence of the concept of the employer brand is reflected in the fact that, on the one hand, talented and qualified graduates are looking for companies with a good reputation as an employer. On the other hand, companies are looking for motivated and talented employees who provide performance growth through work activities and generate and distribute a positive image of the company in the labor market (Brusch et al., 2018). The results of the regression analysis recommend that hotels invest and develop the employer brand because this is one way to increase workforce performances. A particularly important dimension of the employer brand whose growth can provide better workforce performance is the employer reputation. This conclusion is also indicated by the results of the correlation analysis. Reputation is a significant dimension in the recruitment process that attracts better and higher quality candidates (Arachchige \& Robertson, 2011). By hiring such candidates and developing a work environment in which employees gain certain benefits (functional, psychological and economic), which also determine the employer reputation, it is possible to achieve high workforce performance in hotel. High workforce performance provides hotels certain benefits such as higher labour efficiency and productivity (Ali \& Musah, 2012).

The research results also indicate that there is a significant difference in the level of accomplished average workforce performances among III and IV category hotels. Such results can be related to the development of the employer's brand. Categories III hotels get better workforce performance (Mean $=4.489$ ) but also achieve a better assessment of the employer brand (Mean $=3.791$ ). The average value of workforce performance of IV category hotels is Mean $=3.667$, while the average assessment of the employer brand for these hotels is Mean $=3.300$.

\section{Conclusion}

The research results provided answers to the asked research questions. Employer brand dimension- employer reputation $($ Mean $=3.882)$ and corporate social responsibility (Mean = 3.804) had the highest, while training and development dimension (Mean $=2.971$ ) had the lowest mean value. Correlation analysis pointed to the strong and medium correlation between the employer brand dimensions and workforce performance. Hypothesis $\mathrm{H}_{1}$ was adopted, i.e. statistically significant impact of employer brand on workforce performance at hotel companies was proved. By investing in the development of employer reputation, both externally and internally, hotels can increase employee results, which will be reflected in the overall business results of the hotel. Hypothesis $\mathrm{H}_{2}$ was also adopted, which meant that there was a statistically significant difference in the level of accomplished average workforce performance among different category hotels. This difference in workforce performance can be interpreted in the context of the employer's brand development. 
The conducted research had several limitations. The first limitation referred to the sample size. Subjects' response rate was $8 \%$, which was not sufficient to make conclusions which would be valid for the entire hotel industry in the Republic of Serbia. As data were collected by means of a questionnaire, low response rate pointed to the lack of interest of hotel managers to take part in scientific research. The second limitation of the research referred to the way of perceiving workforce performance. Namely, the analyzed variable was expressed in qualitative way, but in order to make a realistic overview of employees work results, quantitative indicators (productivity, work efficiency, added value per employee, net profit per employee, etc.) should be included. The third limitation was related to the assessment of employer brand dimensions. As the questionnaires were filled out only by hotel managers, being the individuals competent for assessing workforce performance, employer brand dimensions were not assessed by employees. If other employees had been included in the assessment procedure, the results of employer brand dimensions would have probably been different.

Practical implications and proposals for future research. Research results clearly indicated that the company could have a significant impact on workforce performance by developing employer brand. This confirmed the assumption on the importance of human resources for hotel companies and the need to develop employer brand which would improve employees' efficiency. Employer reputation was a dimension which had statistically significant impact on workforce performance. This was expected, as managers who filled out the questionnaire assessed employer reputation as most developed dimension at the hotels, which was supported by the mean value (Mean=3.882). Additionally, the results of correlation analysis demonstrated that the employer reputation had the strongest correlation with workforce performance. Arasanmi and Krishna (2019), Maurya and Agarwal (2018) and Moroko and Uncles (2008) also discussed the importance of correlation between employer reputation and employer brand. As a reflection of business culture and employer's relationship with employees, the reputation was expressed in the form of company ranking at the labor market. Employer reputation was the result of all the benefits that the company had provided to its stakeholders, in this case- employees. However, hotel managers were very worried about the insufficient development of employee training and development dimension (Mean=2.971). The results pointed to low investment in professional advancement, knowledge and abilities of employees, which would have positive impact on their efficiency and productivity. Qualifications, knowledge and skills were crucial hotel resources which were relevant for guest satisfaction as well. Future research could be based on the expansion of workforce performance in terms of introducing appropriate dimensions (task performance, contextual performance, etc.) or introducing quantitative indicators of workforce. Furthermore, larger number of hotels and employees could be included in the research of employer brand dimensions in the future. In this way, researchers could make a comparative analysis of the development of employer brand from the viewpoint of employees and from the viewpoint of hotel managers.

\section{References}

1. Agencija za privredne registre Republike Srbije [Business Registry Agency of the Republic of Serbia] (2017). Retrieved March 15, 2017 from https://www.apr.gov.rs/

2. Ahmad, T., Farrukh, F., \& Nazir, S. (2015). Capacity building boost employees performance. Industrial and Commercial Training, 47(2), 61-66. https://doi.org/10.1108/ICT-05-2014-0036

3. Aleksić Glišović, M., Jerotijević, G., \& Jerotijević, Z. (2019). Modern approaches to employee motivation. Ekonomika, 65(2), 121-133. https://doi.org/10.5937/ekonomika1902121A 
4. Ali, M. H., \& Musah, M. B. (2012). Investigation of Malaysian higher education quality culture and workforce performance. Quality Assurance in Education, 20(3), 289-309. http://dx.doi.org/10.1108/09684881211240330

5. Ambler, T., \& Barrow, S. (1996). The employer brand. The Journal of Brand Management, 4(3), 185-206.

6. Arachchige, B., \& Robertson, A. (2011). Business student perceptions of a preferred employer: A study identifying determinants of employer branding. The IUP Journal of Brand Management, 8(3), 25-46.

7. Arasanmi, C., \& Krishna, A. (2019). Employer branding: Perceived organisational support and employee retention - the mediating role of organisational commitment. Industrial and Commercial Training, 51(3), 174-183. https://doi.org/10.1108/ICT-102018-0086

8. Baumann, C., Hamin, H., Tung, R., \& Hoadley, S. (2016). Competitiveness and workforce performance: Asia vis-à-vis the "West". International Journal of Contemporary Hospitality Management, 28(10), 2197-2217. https://doi.org/10.1108/IJCHM-12-2014-0617

9. Benraiss-Noailles, L., \& Viot, C. (2020). Employer brand equity effects on employees well-being and loyalty. Journal of Business Research. Article in press. https://doi.org/10.1016/j.jbusres.2020.02.002

10. Berthon, P., Ewing, M., \& Hah, L. L. (2005). Captivating company: Dimensions of attractiveness in employer branding. International Journal of Advertising, 24(2), 151172.

11. Bitmiş, M. G., \& Ergeneli, A. (2013). The role of psychological capital and trust in individual performance and job satisfaction relationship: A test of multiple mediation model. Procedia - Social and Behavioral Sciences, 99, 173-179. https://doi.org/10.1016/j.sbspro.2013.10.483

12. Brusch, I., Brusch, M., \& Kozlowski, T. (2018). Factors influencing employer branding: Investigations of student perceptions outside metropolitan regions. International Journal of Quality and Service Sciences, 10(2), 149-162. https://doi.org/10.1108/IJQSS-09-20170085

13. Chawla, P. (2020). Impact of employer branding on employee engagement in business process outsourcing (BPO) sector in India: Mediating effect of person-organization fit. Industrial and Commercial Training, 52(1), 35-49. https://doi.org/10.1108/ICT-06-20190063

14. Chhetri, P., Gekara, V., Manzoni, A., \& Montague, A. (2018). Productivity benefits of employer-sponsored training: A study of the Australia transport and logistics industry. Education + Training, 60(9), 1009-1025. https://doi.org/10.1108/ET-02-2017-0029

15. Davies, G., Mete, M., \& Whelan, S. (2018). When employer brand image aids employee satisfaction and engagement. Journal of Organizational Effectiveness: People and Performance, 5(1), 64-80. https://doi.org/10.1108/JOEPP-03-2017-0028

16. Grubor, A., Berber, N., Aleksić, M., \& Bjekić, R. (2020). The influence of corporate social responsibility on organizational performance: A research in AP Vojvodina. The Annals of the Faculty of Economics in Subotica, 56(43), 3-13. https://doi.org/10.5937/AnEkSub2001003G

17. Itam, U., Misra, S., \& Anjum, H. (2020). HRD indicators and branding practices: A viewpoint on the employer brand building process. European Journal of Training and Development. https://doi.org/10.1108/EJTD-05-2019-0072

18. Khan, M. N., Malik, S. A., \& Janjua, S. J. (2019). Total Quality Management practices and work-related outcomes: A case study of higher education institutions in Pakistan. International Journal of Quality \& Reliability Management, 36(6), 864-874. https://doi.org/10.1108/IJQRM-04-2018-0097 
19. Maurya, K. K., \& Agarwal, M. (2018). Organisational talent management and perceived employer branding. International Journal of Organizational Analysis, 26(2), 312-330. https://doi.org/10.1108/IJOA-04-2017-1147

20. McAfee, B., \& Champagne, P. (1993). Performance management: A strategy for improving employee performance and productivity. Journal of Managerial Psychology, 8(5), 24-32.

21. Moroko, L., \& Uncles, M. (2008). Characteristics of successful employer brands. Journal of Brand Management, 16(3), 160-175. https://doi.org/10.1057/bm.2008.4

22. Musah, M. B., Ali, H. M., Vazhathodi al-Hudawi, S. H., Tahir, L. M., Daud, K. B., Said, H., \& Kamil, N. M. (2016). Organisational climate as a predictor of workforce performance in the Malaysian higher education institutions. Quality Assurance in Education, 24(3), 416-438. https://doi.org/10.1108/QAE-10-2014-0048

23. Nunnally, J. C. (1978). Psychometric theory. New York: McGraw-Hill.

24. Ognjanović, J., \& Slavković, M. (2019). Impact of employer brand on employees statisfaction in Serbian hotel enterprises. In D. Cvijanović et al. (Eds.), Tourism in Function of Development of the Republic of Serbia - Tourism as a Generator of Employment (pp. 254-271). Vrnjačka Banja, Serbia: Faculty of Hotel Management and Tourism in Vrnjačka Banja University of Kragujevac.

25. Otoo, F. N. K., Otoo, E. A., Abledu, G. K., \& Bhardwaj, A. (2019). Impact of human resource development practices on pharmaceutical industry's performance: The mediating role of employee performance. European Journal of Training and Development, 43(1/2), 188-210. https://doi.org/10.1108/EJTD-07-2017-0061

26. Pallant, J. (2009). SPSS: priručnik za preživljavanje [SPSS Survival Manual]. Beograd, Srbija: Mikro knjiga.

27. Rai, A. (2020). An application of the instrumental-symbolic framework in Maritime industry: A study on employer branding among seafarers. Management Research Review, 43(3), 270-292. http://dx.doi.org/10.1108/MRR-04-2019-0181

28. Rana, M. H., \& Malik, M. S. (2017). Impact of human resource (HR) practices on organizational performance: Moderating role of Islamic principles. International Journal of Islamic and Middle Eastern Finance and Management, 10(2), 186-207. https://doi.org/10.1108/IMEFM-04-2016-0060

29. Razak, I. H. A., Kamaruddin, S., \& Azid, I. A. (2012). Workforce competency model (WFCM): An empirical study in Malaysia of a model for maintenance workforce performance evaluation. International Journal of Productivity and Performance Management, 61(1), 24-45. https://doi.org/10.1108/17410401211187499

30. Republički zavod za statistiku Srbije [Statistical Office of the Republic of Serbia]. (2010). Uredba o klasifikaciji delatnosti Republike Srbije [Decree on Activity Classification of the Republic of Serbia]. Retrieved June 20, 2020 from https://www.stat.gov.rs/media/2622/klasifikacija-delatnosti-2010.pdf

31. Saini, G., \& Jawahar, I. M. (2019). The influence of employer rankings, employment experience, and employee characteristics on employer branding as an employer of choice. Career Development International, 24(7), 636-657. https://doi.org/10.1108/CDI-112018-0290

32. Schlager, T., Bodderas, M., Maas, P., \& Cachelin, J. L. (2011). The influence of the employer brand on employee attitudes relevant for service branding: An empirical investigation. Journal of Services Marketing, 25(7), 497-508. http://dx.doi.org/10.1108/08876041111173624

33. Sharma, R., \& Prasad, A. (2018). Employer brand and its unexplored impact on intent to join. International Journal of Organizational Analysis, 26(3), 536-566. https://doi.org/10.1108/IJOA-11-2017-1280 
34. Tanwar, K., \& Prasad, A. (2016). The effect of employer brand dimensions on job satisfaction: Gender as a moderator. Management Decision, 54(4), 854-886. http://dx.doi.org/10.1108/MD-08-2015-0343

35. Tanwar, K., \& Prasad, A. (2017). Employer brand scale development and validation: a second-order factor approach. Personnel Review, 46(2), 389-409. http://dx.doi.org/10.1108/PR-03-2015-0065

36. Zhu, F., Wang, Z., Yu, Q., Hu, T., Wen, Y., \& Liu, Y. (2014). Reconsidering the dimensionality and measurement of employer brand in the Chinese context. Social behavior and personality, 42(6), 933-948. http://dx.doi.org/10.2224/sbp.2014.42.6.933 